\title{
ANALYSIS OF FACTOR FACTORS THAT INFLUENCE THE IMPLEMENTATION OF FINANCIAL MANAGEMENT INFORMATION SYSTEM (SIMDA) FINANCIAL STUDY
}

\author{
Febrina Sinta Fitriani ${ }^{* 1}$, Endang Masitoh. ${ }^{2}$ \\ Batik Islamic University, Indonesia ${ }^{* 12}$ \\ fsinta262@gmail.com
}

\begin{abstract}
The purpose of this study is to empirically examine the influence of the expertise of system users, education and training programs, information technology and top management support for SIMDA Finance in Village Office in Sub-District Jebres Surakarta. The population in this study is the District of Jebres District with a sample using purposive sampling obtained a sample of 30 respondents. The results showed that the variables of system user expertise, education and training programs as well as top management support had a significant effect on SIMDA Finance, while the information technology variable had no effect on SIMDA Finance.
\end{abstract}

Keywords: System User Skills, Education and Training Program, Top Management Support, Information Technology, SIMDA Financial

\section{INTRODUCTION}

The fact that local governments obtain an unqualified opinion from the audit results on the basis of the Regional Government Financial Report conducted by the Examining Board Finance is evidence of the low quality of financial reports produced by local governments (Alfian, 2015). The Local Government Financial Report will each year receive an assessment in the form of an opinion from the Financial Supervisory Agency. When Financial Supervisory Agency gives a Fair Without Exception opinion on this Financial Report, it means that the organization is presented and disclosed in a fair and quality manner. In addition the application of internal control systems can process the existence of an activity that is not in accordance with applicable regulations.

The case that occurred in Surakarta City related to SIMDA, in 2012 only obtained WTP 11 of 36 LKPD, in 2013 obtained WTP 12 of 36 LKPD and in 2014 obtained WTP 15 of 36 LKPD. This is due to the lack of accounting information systems, information technology sources, regional reporting systems and from human resources.
Therefore there is a need for development that is able to obtain financial statements with an unqualified opinion.

The application of SIMDA in Surakarta in its regional financial management processes includes budgeting, administration, accounting and reporting. Although financial management has been divided for the effectiveness of the use of SIMDA Finance itself is still not much known with certainty. For example, from the management of accounting there are journal reports, ledger finances and their translation and cash flow statements. This indicates that the expertise of many SIMDA users has not been able to implement SIMDA.

The official website of BPKP 2019 (www.BPKP.go.id) states that to realize good governance, the Regional Finance Audit Board has set the Regional Management Information System Development as an activity to support the achievement of performance indicators and to support the speed of the government in the regions and the speed of responding to demands Public. As of January 2016, the SIMDA Application Program has been 
JASa (Jurnal Akuntansi, Audit dan Sistem Informasi Akuntansi)

Vol. 4 No. 3/ December 2020

ISSN 2550-0732 print / ISSN 2655-8319 online

implemented or implemented in 425 LGs

from 542 existing Local Governments or

$78.41 \%$ consisting of:

Table.1 developed states that to realize good governance, the Regional Finance Audit Board

\begin{tabular}{clll}
\hline No & \multicolumn{1}{c}{ Implementation Type } & \multicolumn{1}{c}{ Jan 2016 } & \multicolumn{1}{c}{ Dec 2015 } \\
\hline 1 & SIMDA Users & 425 Pemda & 425 Pemda \\
2 & SIMDA Finance & 365 Pemda & 365 Pemda \\
3 & SIMDA BMD & 347 Pemda & 347 Pemda \\
4 & SIMDA Salary & 65 Pemda & 65 Pemda \\
5 & SIMDA Revenue & 55 Pemda & 55 Pemda \\
\hline
\end{tabular}

Source: www.BPKP.go.id

Surakarta City implemented SIMDA in 2006 and developed into an online base in 2016. As research Hertanto, Domai, \& Amin (2016) used the same system as that implemented by SIMDA in Surakarta City using version 2.7.0.6 as a refinement of the previous versions. The SIMDA has included laws relating to financial management, namely as stipulated in Law Number 17 of 2003 concerning State Finance, Law Number 1 of 2004 concerning State Treasury, thereby recording, documenting and reporting done manually transferred to a computerized system that has been integrated with each SKPD. Based on the description above, then in order to understand the problems associated with the problem of Regional Financial Management Information System (SIMDA) in Kelurahan Se District Jebres, the authors conducted a literature study of the development of financial management management systems for local governments. Then the authors conducted a study on the implementation of financial management that has been done so far to take the title, "Analysis of Factors Affecting Implementation of Management Information Systems Areas (SIMDA) Finance (Case Study Around the Village District of Jebres Surakarta)".

Agency Theory base contractual relations so that members within the company, where the principal and agent are the main actors. Principals are parties who give mandates to agents to act on behalf of principals, while agents are parties who are mandated by principals to run the company. The agent is obliged to account for what has been mandated by the principal to him. The essence of Agency Theory or agency theory is designing appropriate contracts to align the interests of principals and agents in the event of a conflict of interest. The Regional Management Information System (SIMDA) order to realize the practice of regional financial management that is fast, precise, and accurate, the Financial and Development Supervisory Agency (BPKP) has developed a computer application system that can process financial transaction data into financial reports that can be utilized at any time, namely the Regional Management Information System (SIMDA) a technology-based application system developed to support the achievement of accountability for local governments both at the reporting level (SKPD) ). This application is expected to help local governments in the preparation of planning and budgeting, as well as the implementation and administration of the Regional Budget and accountability of the Regional Budget and BPKP emphasized that this system is intended to facilitate the SIMDA input. One 
SIMDA application is financial SIMDA which is an application program aimed at assisting local governments in managing their regional finances (Pratama, 2016). Local governments can carry out integrated regional financial management, starting from budgeting, administration to accounting and reporting. Expertise of User Systems Research conducted by Kamal \& Langgeng (2014) states the user's understanding of information technology determines the success of an information system, otherwise ignorance or anxiety of users of the new system can cause failure to use information technology. Improved user understanding of information systems also affects the success in utilizing information technology. This study illustrates the expertise of system users must have an understanding of the SIMDA Financial system in identifying data, accessing data and interpreting data and so on. If you already have a good understanding of the SIMDA Financial system, the flow of information and / or data collection to produce a financial report will run well. Education and Training Program, a user will be said to be able to operate the system if he has received a learning process about the system used. Montazemi, 1988 in Komara, (2005) writes that with education and training, users can get the ability to identify their information requirements and the seriousness and limitations of $\mathrm{SI}$ and this ability can lead to improved performance. Information technology in government has developed into an application called SIMDA. SIMDA is an application issued by BPKP to facilitate government affairs. The existence of the SIMDA application program, the government expects to be able to provide more benefits in carrying out regional financial management, preparation of planning and budgeting, as well as the implementation and administration of APBD and APBD accountability. Information technology will always be developed towards a better direction, as well as the implementation of SIMDA information technology there is a need for system development because if it is known the SIMDA system always develops to a newer system. Top Management Support Thong, et al. (1996) state that if the level of top management support is low then top management may not be involved in aspects of implementing AIS, they find that management commitment increases the effectiveness of information systems because they provide the resources needed for development projects DRAIN. Top management support has an influence on information systems, as well as SIMDA, because the lack of support from top management will affect the Regional Government Financial Reports. Top management will be responsible for reporting to the government. If the financial statements are not in accordance with the standards set by the government, the financial statements will not get the title of Fair without Exception.

Hypothesis Formulation The

Relationship between system user expertise with SIMDA Finance.

Research by Pirade, Saleh, and Amar (2013) in Khoirunnisa, (2016) the more a person has high expertise, the more the individual has high selfconfidence in his ability to complete tasks well. Based on the description above, the researcher concludes that user expertise has an effect on SIMDA Finance in line with Nasution research, (2019).

$\mathrm{H} 1$ : User expertise influences the application of SIMDA Finance.

Relationship between programs education and training with SIMDA Finance.

The existence of education and training on the SIMDA Financial system can increase knowledge and participate in programs or developments that are issued. Education and training programs 
are good if carried out continuously to make it easier for users to recognize the development of the SIMDA Financial system. From the description above, the researchers conclude that the education and training program has an effect on SIMDA Finance. In line with research conducted by Purnawati, Astuti, \& Kristianto (2018).

H2: Education and Training Programs affect the Application of SIMDA Financial

Relationship between Information Technology and SIMDA Finance.

The government is obliged to develop information technology systems through the development of systems one of which is SIMDA Finance. SIMDA Finance is intended to facilitate the implementation of regional financial management, preparation of planning and budgeting, as well as the implementation and administration of APBD and APBD accountability. From the description above, the study concludes that information technology has an effect on SIMDA Finance, in line with research by Nugroho, Astuti, \& Kristianto, (2018).

H3: Information technology influences the application of SIMDA Finance.

Relationship between top management support and SIMDA Finance.

Management support influences the running of the SIMDA Financial system. Top management support will motivate individuals to use the SIMDA Financial system because of the attention and support of financial and non-financial resources and training so that individuals can understand the use of the SIMDA Financial system. Based on the description above, the researcher concludes that top management support has an effect on SIMDA Finance, in line with research conducted by Alfian, (2015).

H4: Top management support influences the application of SIMDA Finance.

\section{METHODS}

Type of research uses a quantitative approach that is by testing a hypothesis. Analyzed using descriptive analysis to determine the effect of variable $X$ to variable $Y$.

\section{Variables and Measurement of the Independent Variables User Expertise System}

The user expertise variable with instruments developed by Kasse (2015) in Sitorus, (2017), namely: can use the SIMDA Finance application without the help of people others, can use SIMDA Finance even though they have never before, can use SIMDA Finance without a manual.

\section{Education and Training}

Program Variables of education and training programs with instruments developed by Wahyudi, Tobing, \& Handriyono, (2018), namely: Budgeting or planning training and Budget Implementation Documents (DPA), Administration training (entry data creation of SPP and SPM), Training preparation of financial reporting.

\section{Information Technology}

Variable information technology is measured by instruments: data accessibility relating to ease in finding the required data, authority in accessing data, timeliness in completing tasks, ease in operating the system. Financial reporting preparation training.

\section{Top Management Support The top}

management support variable is measured by the instrument: how much is top management's involvement in the progress of the SIMDA Financial system, how much top management wants to develop the SIMDA Financial system.

\section{Dependent}

Variables The SIMDA Financial variable is measured by instruments: the success of performance each village office, system user job satisfaction, information functions for external and internal parties, financial functions, 
contributions SIMDA Financial \& the latest system updates.

\section{Hypothesis Test \\ Multiple Regression Analysis}

Analysis of the data used in this study is multiple linear regression analysis with the following equation:

$$
\begin{aligned}
& \mathrm{SK}=\alpha+\beta 1 \mathrm{KP}+\beta 2 \mathrm{PPI}+\beta 3 \mathrm{TI}+\beta 4 \mathrm{DTP} \\
& +\mathrm{e}
\end{aligned}
$$

Description:

$$
\begin{array}{ll}
\text { SK } & \text { :SIMDA Financial } \\
\alpha & : \text { Constants } \\
\text { KP } & \text { :User Expertise } \\
\text { PPI } & \text { :Education and Training Program } \\
\text { IT } & \text { :Information Technology } \\
\text { DTP } & : \text { TOP Management Support } \\
\text { e } & \text { : error }
\end{array}
$$

\section{RESULTS AND DISCUSSION General Data Descriptive Research}

This research uses the population of Kelurahans in the Sub-District of Jebres Surakarta with samples using purposive sampling. The sample in this study is village officials who understand and know about the SIMDA Financial system. The number of villages is 11 villages with respondents selected 3 employees per village with a total sample of 33 samples.

\section{Test Instruments \\ Validity Test Validity}

test in this study was conducted by looking at $r$ count greater than $r$ tables with a significance of $5 \%$, then the data will be declared valid. The results state that all instruments per variable are declared valid because $r$ count is greater than $r$ table at a significant level of $5 \%$.

\section{Test Reliability}

Test Reliability is used to determine the extent to which the results of measurements using the same object will generate the same data. The minimum requirement to be declared reliable is the value of a valid index is the value of the validity index $\geq 0.7$ (Sugiyono, 2013). The result is that all of these variables at a level of reliability high are declared valid according to the minimum requirements of Sugiyono (2013) which states the index value is valid if the value is Cronbach Alpha more than 0.70 .

\section{Classical Assumptions Test Normality Test}

Kolmogorov Smirnov Is a normality test used in this study by looking at the sig value $>0.05$ indicating research data are distributed normally.

Table 1. Test Results for Normality

\begin{tabular}{lcccc}
\hline Variable & $\mathrm{N}$ & Sig & Std & Ket. \\
\hline $\begin{array}{l}\text { Unstandardized } \\
\text { Residual }\end{array}$ & 30 & 0.173 & $>0.05$ & Normal \\
\hline
\end{tabular}

Source: processed data 2018

Asymp Value. Sig of 0.173 is greater than the standard of 0.05 so it can be concluded that the data are distributed normally, thus this normality test shows that the normality assumption is fulfilled.

\author{
Multicollinearity Test \\ Multicollinearity \\ test aims to test whether the \\ regression model found a correlation \\ between independent variables, if the \\ value tolerance $>0.05$ and VIF value $<5$, \\ then it means that there is no \\ multicollinearity to the data tested.
}


Table 2. Multicollinerity Test Results

\begin{tabular}{cccc}
\hline \multirow{2}{*}{ Variable } & \multicolumn{2}{c}{ Collinearity Statistics } & \\
\cline { 2 - 3 } & Tolerance & VIF & \multirow{2}{*}{ Information } \\
\hline X1 & 0.595 & 1,681 & Free Multicollinearity \\
X2 & 0,665 & 1,504 & Free Multicollinearity \\
X3 & 0.567 & 1,764 & Free Multicollinearity \\
X4 & 0,468 & 2,139 & Free Multicollinearity \\
\hline
\end{tabular}

Source: processed data 2020

The output results show no symptom of each independent variable multicollinearity. VIF values of all variables have values less than 5 and tolerance values of all variables are greater than 0.05 , so the variables do not have multicollinearity problems.

\section{Test Autocorrelation}

correlation test is used to determine whether or not the classic assumption deviation of autocorrelation between residuals of the observations to other observations in the regression model. If $\mathrm{d}$ lies between $\mathrm{dU}$ and (4-dU) then the null hypothesis is accepted, meaning there is no correlation.

Table 3. Autocorrelation Test Results for the

\begin{tabular}{ccc}
\hline Model & $\begin{array}{c}\text { Std. Error of the } \\
\text { Estimate }\end{array}$ & Durbin-Watson \\
\hline 1 & 0.5031 & 2.1337 \\
\hline \multicolumn{3}{c}{ Source: processed data 2020 }
\end{tabular}

Output results show that the value of durbin-watson is 2.1337 which means that there is no autocorrelation. These results are inferred from a dU value of 1.739 smaller than 2.1337 and less than (4-dU) 2.2614, so the conclusion of the study data is asymptomatic autocorrelation.

\section{Heteroscedasticity Test Heteroscedasticity}

test aims to test whether there is a difference in variance from the residuals of one observation to another. It is said that there are no symptoms of heteroscedasticity, if the significance value $>0.05$.

Table 4. Results of the Heteroscedasticity Test

\begin{tabular}{ccc}
\hline Var. Independent & $\mathrm{t}$ & $\mathrm{Sig}$ \\
\hline X1 & 0,591 & 0,560 \\
X2 & $-0,366$ & 0,718 \\
X3 & 0,772 & 0,448 \\
X3 & $-0,067$ & 0,947 \\
\hline
\end{tabular}

Based on the output table above, it was concluded that there was no heteroscedasticity, it was concluded from the Sig. of all variables exceeding the 0.05 rule limit.

\section{Test Regression Model Regression}

Testing multiple linear regression model was conducted to determine the independent variable on the dependent variable.

$$
\begin{aligned}
& \mathrm{SK}=\alpha+\beta 1 \mathrm{KP}+\beta 2 \mathrm{PPI}+\beta 3 \mathrm{TI}+\beta 4 \mathrm{DTP} \\
& +\mathrm{e}
\end{aligned}
$$

Description:

SK : SIMDA Financial 
JASa (Jurnal Akuntansi, Audit dan Sistem Informasi Akuntansi)

Vol. 4 No. 3/ December 2020

ISSN 2550-0732 print / ISSN 2655-8319 online

$\begin{array}{llll}\text { a } & \text { :Constants } & \text { IT } & : \text { Information Technology } \\ \text { KP } & \text { User Expertise } & \text { DTP } & : \text { TOPSupport } \\ \text { PPI } & : \text { Mducation and Training } & & : \text { error }\end{array}$

Table 5. Multiple Linear Regression Analysis

\begin{tabular}{lcc}
\hline & \multirow{2}{*}{ Model } & \multicolumn{2}{c}{ Unstandardized Coefficients } \\
& $\mathrm{B}$ & Std. Error \\
\hline Constant & -1.934 & 1.489 \\
X1 & 0.177 & 0.081 \\
X2 & 0.142 & 0.050 \\
X3 & -0.014 & 0.022 \\
X4 & 0.785 & 0.069 \\
\hline
\end{tabular}

Source: processed data 2020

The Equation multiple regression obtained from the results is $\mathrm{SK}=-1.934$ $+0.177 \mathrm{KP}+0.142 \mathrm{PPI}-0.014 \mathrm{TI}+$ $0.785 \mathrm{DTP}+\mathrm{e}$

\section{Feasibility Test Model F}

Test $f$ is used to find out the equation whether the study is suitable or not. The $F$ test is seen through the probability value that if the value of sig $<0.05$ and $f$ arithmetic is greater than $f$ table then there is a significant influence between the independent variables on the dependent variable in each equation in the study.

Table 6. Model Feasibility Test Results (F)

\begin{tabular}{ccccc}
\hline$F_{\text {arithmetic }}$ & $\mathrm{F}_{\text {table }}$ & Sig & Std & Information \\
\hline & & & & \\
75.848 & 2.98 & 0.001 & 0.05 The & $\begin{array}{l}\text { model used is feasible or } \\
\text { fit }\end{array}$
\end{tabular}

Source: data processed 2020

Calculated $F$ value 75.848 with sig 0.001 so that it can be concluded that the expertise of system users, educational programs and training, information technology and top management support have an effect on SIMDA Finance. This happens because the calculated $f$ value is greater than the $f$ table (75.848> 2.98) and the sig value is smaller than the standard $(0.001$ $<0.05)$.

\section{Hypothesis}

Test The t test was conducted to provide results about the effect of the independent variables on the dependent partially in the research equation model.

Table 7. Hypothesis Test Results (t Test)

\begin{tabular}{cccccl}
\hline Var. Inde & $\mathrm{t}_{\text {arithmetic }}$ & $\mathrm{t}_{\text {table }}$ & Sig & Std & Results \\
\hline X1 & 2,181 & 2,056 & 0,039 & $<0,05$ & Received \\
X2 & 2,860 & 2,056 & 0,008 & $<0.05$ & Received \\
X3 & $-0,661$ & 2,056 & 0.515 & $<0.05$ & Rejected \\
X4 & 11,43 & 2,056 & 0,001 & $<0,05$ & Received \\
\hline
\end{tabular}

Source: processed data 2020

The above table shows that the variable expertise users of the system, education and training programs as well as top management support affect the SIMDA financial and information technology does not affect the SIMDA finance 


\section{Test of determination $\mathbf{R}^{2}$}

Test of determination $\mathrm{R} 2$ is performed to measure the percentage of the ability of independent variables in

the effect on the dependent variable. This study conducted a determination test by looking at the adjusted $\mathrm{R}$ Square value.

Table 8. Results of Determination Test $\mathbf{R}^{2}$

\begin{tabular}{cccl}
\hline$R$ & $R^{2}$ & Adj $R^{2}$ & \multicolumn{1}{c}{ Ket. } \\
\hline 0.952 & 0.906 & 0.891 & $\begin{array}{l}\text { Variables can explain variations in the } \\
\text { dependent variable }\end{array}$
\end{tabular}

Source: processed data 2020

The output results from the table above shows the coefficient value in model 1 , adjusted $\mathrm{R} 2$ shows the value of 0.891 which means $89.1 \%$ of the independent variables in this study have an influence on the dependent variable while the remaining $10,9 \%$ is influenced by other variables not included in this study

\section{CONCLUSION}

The results of the study stated that the hypotheses variable system user expertise, education and training programs as well as top management support affect the SIMDA Financial results are in line with Nugroho, Astuti, \& Kristianto (2018), Purnawati, Astuti, \& Kristianto (2018) and Kurniawati (2018) and the information technology variable hypothesis had no effect on SIMDA Finance in line with Arif's research (2017).

\section{REFERENCES}

Alfian, M. (2015). Supporting Factors of SIMDA Implementation and Its Impact on the Quality of Financial Statements in Kulon Progo Regency SKPD. Journal of Economics and BusinessVolume XVIII No. 3, December 2015.

Hertanto, Y.,Domai, T., \& Amin, F. (2016). Implementation of Regional Financial Management Information System (SIMDA) on the Effectiveness of Financial Reporting (Study of the Regional Financial and Asset Management
Agency in Blitar District). Publisia (Journal of Public Administration) Volume 1, Number 2, October .

Kamal, B.,\& Lasting, AN (2014). Analysis of Factors Influencing Implementation SIMDA and Quality of Financial Statements in SKPD. Economics \& Business Research Festival .

Khoirunnisa, E. (2016). Effect of Effectiveness of Use, Trust, Utilization, and Expertise on Regional Management Information System Technology (SIMDA) on the Performance of Individual Employees (Empirical Study on Work Units of Surakarta City Regional Apparatus).

Komara, A. (2005). Analysis of Factors Affecting Accounting Information System Performance. SjNA 8.

Nasution, DA (2019). FactorsThat Influence the Performance of Users in the Regional Management Financial Information System of the Government of North Sumatra Province. Journal of Business \& Public Accounting Vol.QO No.1 August , 101-114.

Nugroho, AA, Astuti, DS, \& Kristianto, D. (2018). Influence of Information Technology, User Technical Capability, Top Management Support and Task Complexity on Accounting Information System Performance. Journal of Accounting and 
InformationTechnology Systems Vol. 14 No. December 4 , 507 518.

Pratama, SY (2016). Evaluation of the Implementation of the Regional Financial Management Information System (SIMDA) at the Regional Secretariat Finance Bureau of East Kalimantan Province. Journal of Administrative Reform, Vol.4 No.2, April-June , 50-62.

Purnawati, RA, Astuti, DS, \& Kristianto, D. (2018). The Influence of User Skills, Training and Education Programs, Organizational Size, and Formalization of System Development on Accounting Information System Performance. Journal of Accounting and Information Technology Systems Vol. 14 April Special Edition , 244 - 252.

Sitorus, MT (2017). Factors That Influence the Performance of Regional Management Information System (SIMDA) Users in Asahan District Government. University of North Sumatra Institutional Repository.

Sugiyono (2013). Qualitative Quantitative Research Methods and R\&D. Bandung: CV Alfabeta.

Thong, JL, Chee-Sing, Y., \& Raman, KS (1996). Top Management Support, External Expertise and Information Systems Implementation in Small Businesses. Information Systems Research, 7 (2), 248-267.

Wahyudi, ES, Tobing, DS, \& Handriyono. (2018). The Influence of Personal Engineering Capabilities, System Operator Training on Financial Regional Management System (SIMDA) Performance Through Service Adoption in Bondowoso Regency Government. Bisma Journal of Business and Management Vol. 12, No. 3September, 367 - 381. 